\title{
QUAERERE DEUM FUNDAMENTEM KULTURY EUROPEJSKIEJ W ŚWIETLE PRZEMÓWIENIA BENEDYKTA XVI
}

$(12.09 .2008)$

DOI: http://dx.doi.org/10.12775/TiCz.2020.054

Streszczenie. Benedykt XVI, poszukując źródeł kultury europejskiej, wskazuje na życie monastyczne, zbudowane na zachwycie nad Słowem. U podstaw tego zachwytu leży pragnienie poszukiwania Boga. Każdy intelektualny wysiłek miał pomagać w otwarciu się na Prawdę objawioną w Bożym Słowie. Słowo kształtowało indywidualną relację z Bogiem, zapraszało do dialogu i budowało w ten sposób potrzebę życia we wspólnocie. $\mathrm{Z}$ troski o Słowo Boże zrodziła się troska o słowo ludzkie, stąd systematyczna refleksja, jaka dokonywała się w klasztornych szkołach, bibliotekach, a następnie przeradzała się w modlitewny dialog ze Stwórcą wyrażony w modlitwie i śpiewie. Efektem owego poszukiwania Boga jest całokształt wytworów działania ludzkiego intelektu, a więc szeroko pojęta kultura, która od samego początku czerpie z chrześcijańskich wzorców. Benedykt XVI wskazuje na potrzebę ewangelizacji, mającej budzić na nowo pragnienia poszukiwania Boga poprzez kulturę, która we współczesnym świecie przeżywa kryzys oderwania od wartości religijnych. Przemówienie Benedykta wygłoszone w Kolegium Bernardynów jest więc pełnym nadziei wołanie o powrót do źródła, jakim jest Słowo, kształtujące ludzki intelekt na obraz i podobieństwo Stwórcy.

Słowa kluczowe: Benedykt XVI; kultura europejska; poszukiwanie Boga; monastycyzm; ewangelizacja. 
Abstract. Quaerere Deum as the Foundation of European Culture in the Light of the Speech of Benedict XVI (12.09.2008). Benedict XVI, searching for sources of European culture, points to a monastic life built on admiration of the Word of God. At the core of this delight lies the desire to seek God. The Word of God shaped an individual relationship with God, invited to dialogue and thus built the need for community life. The result of seeking God is the whole product of the action of the human intellect, and thus a broadly understood culture that draws from Christian patterns from the very beginning. Benedict XVI points to the need for evangelization, which is to revive the desire to seek God through a culture, which suffers from a crisis of detachment from religious values in modern world. Benedict's speech at the Bernardine's College is therefore a hopeful call for a return to the source, which is the Word of God, which shapes the human intellect in the image and likeness of the Creator.

Keywords: Benedict XVI; European culture; searching for God; monasticism; evangelization.

\section{WSTĘP}

Benedykt XVI w swoim papieskim nauczaniu wielokrotnie nawiązuje do trudnej sytuacji, w jakiej znalazła się kultura europejska. Podejmuje w ten sposób bogatą spuściznę swego poprzednika, ukazując ścisły związek kultury z wiarą. Postępujący kryzys Kościoła w Europie stanowił jeden $\mathrm{z}$ największych problemów, z jakimi musiał sobie poradzić następca Jana Pawła II. W niniejszym artykule odwołuję się do przemówienia, które wygłosił Benedykt XVI w Kolegium Bernardynów w Paryżu 12 września 2008 r., w którym to przemówieniu przekonywał, że Europa ze swoją kulturą od początku kształtowania swej świadomości zbudowana jest na poszukiwaniu Boga.

\section{BENEDYKT XVI JAKO ZNAWCA KULTURY ZACHODU}

Benedykta XVI cechuje nie tylko teologiczna przenikliwość, z jaką patrzy na rzeczywistość świata XXI w., doskonale rozumie także kulturę, która pozwala ocenić duchową kondycję świata i człowieka. Roberto Regoli, bazując na wypowiedzi kard. Francis George’a, twierdzi, że kard. Joseph Ratzinger został wybrany na urząd papieski właśnie ze względu 
na znajomość historii i kultury Europy Zachodniej. Umiejętność stawiania trafnej diagnozy stanu współczesnej kultury daje się dostrzec dzięki dorobkowi naukowemu Josepha Ratzingera sprzed wyboru na papieża. W przededniu śmierci Jana Pawła II, jako prefekt Kongregacji Nauki Wiary, wygłosił w Subiaco wykład na temat kryzysu kultur, w którym to wykładzie podkreślał, że kryzys wiary i kryzys kultury pozostają ze sobą w ścisłej zależności. Zwrócił uwagę na niebezpieczeństwo, jakie niesie ze sobą absolutyzacja kultury w jej oświeceniowym kształcie ${ }^{2}$. Także w swojej ostatniej homilii wygłoszonej na krótko wyborem na urząd papieski kard. Ratzinger odniósł się w sposób zdecydowany do duchowej kondycji Kościoła i Europy, zwracając uwagę na relatywizm, jaki cechuje współczesną Europę z jej kulturą. Dyktaturze relatywizmu Ratzinger przeciwstawił prawdziwy humanizm, którego fundamentem jest osoba Jezusa Chrystusa ${ }^{3}$.

Benedykt XVI w czasie swego pontyfikatu wielokrotnie dawał do zrozumienia, że istnieje konieczność pogodzenia teorii z praktyką w odniesieniu do kształtowania kultury współczesnego świata. Jego troska o kulturę nie sprowadzała się jedynie do nauczania i stawiania diagnozy, ale i do działania (otwarcie Stolicy Apostolskiej na nowe możliwości techniczne, korzystanie z portali społecznościowych, kontynuacja ŚDM itp.).

Joseph Ratzinger/Benedykt XVI wielokrotnie odwoływał się w swoim nauczaniu do czasów, w których kultura europejska kształtowała się na fundamentach chrześcijaństwa. W wygłoszonym 1 kwietnia 2005 r. w Subiaco wykładzie Joseph Ratzinger zauważył, że chrześcijaństwo otrzymało w Europie kulturalne i intelektualne znamię, mimo iż wywodzi się z innego kręgu kulturowego, jeśli wziąć pod uwagę jej geograficzne korzenie. Jednocześnie to chrześcijaństwo kształtowało kulturę Europy po upadku antycznego porządku kulturowego. Z drugiej strony Joseph Ratzinger zauważył wtedy, że ta sama Europa zrodziła naukowy racjo-

1 Por. R. Regoli, Benedykt XVI. Wielki papież czasu kryzysu, Kraków, 2017, s. 26.

2 Por. J. Ratzinger, Europa Benedykta w kryzysie kultur, Częstochowa 2005, s. $50-53$.

${ }^{3}$ Por. tenże, Ku dojrzałości wiary w Chrystusa. Homilia w czasie Mszy „pro eligendo pontifice”, „L'Osservatore Romano”, edycja polska, 2005 (6), s. 30. 
nalizm stojący u podstaw współczesnej kultury wykluczającej Boga ze świadomości społecznej.

W swoim nauczaniu Benedykt XVI, odnosząc się do kultury, ma na myśli jej bardzo szerokie rozumienie jako całokształt wytworów ludzkiej działalności, mówi o kulturze myśli ludzkiej w odniesieniu do całego dorobku cywilizacji. Mówiąc o kulturze europejskiej czy kulturze Zachodu, ma na myśli tożsame $\mathrm{z}$ nią cywilizację europejską czy cywilizację Zachodu. Dlatego też kryzys cywilizacyjny jest przede wszystkim rozpatrywany przez papieża jako kryzys kultury ${ }^{5}$.

\section{PRZEMÓWIENIE W KOLEGIUM BERNARDYNÓW}

W czasie pielgrzymki do Francji w dniach 12-15 września 2008 r. papież Benedykt XVI wygłosił jedno z najważniejszych przemówień dotyczących bezpośredniego oddziaływania chrześcijańskiej wiary na kulturę. Przemówienie to odbyło się w Kolegium Bernardynów w Paryżu 12 września 2008 roku.

Kolegium Bernardynów stanowi bardzo wyraźny znak, który - ze względu na swoje historyczne znaczenie, nie tylko dla Francji, ale i dla Europy - jeszcze bardziej dodaje mocy brzmieniu papieskiego przesłania. Jest dziś szczególnym miejscem dialogu chrześcijaństwa ze współczesnym światem i jednocześnie jedna z najbardziej znaczących instytucji katolickich we Francji. Kolegium to dawny klasztor cystersów, którego budowę rozpoczęto w 1248 r. z inicjatywy papieża Innocentego IV. Od tej pory miejsce to aż do rewolucji francuskiej służyło kształceniu cysterskich mnichów, a przez to zaliczane było do najważniejszych centrów intelektualnych średniowiecznej Europy. Po restauracji, od 2008 r. Kolegium otrzymało na powrót swoje pierwotne przeznaczenie - stało się otwartym dla wszystkich centrum badań i debaty Kościoła i społeczeństwa na temat człowieka i jego przyszłości ${ }^{6}$.

${ }^{4}$ Por. tenże, Europa Benedykta $w$ kryzysie kultur, Częstochowa 2005, s. 46.

${ }^{5}$ Por. M. Kindziuk, Benedykt XVI o kulturze, http://e-civitas.pl/benedykt-xvi-o-kulturze (dostęp: 12.11.2019).

${ }^{6}$ Por. Osiem wieków historii, na podstawie https://www.collegedesbernardins.fr/ qui-sommes-nous/huit-siecles-dhistoire (dostęp: 29.10.2019). 
Przemówienie wygłoszone w Paryżu daje się podzielić na dwie zasadnicze części. Pierwsza z nich to dogłębna analiza kultury monastycznej, która leży u fundamentów kultury europejskiej. Opis kultury monastycznej daje się zamknąć w ramach benedyktyńskiej maksymy ora et labora, co pozwala rozpatrywać monastycyzm z punktu widzenia kultury słowa i kultury pracy. Kultura słowa i kultura pracy pozwalają zaspokoić pragnienie poszukiwania Boga, otwierają człowieka na rozpoznanie Boga, który objawił się w Słowie i w historii, by następnie tego Boga głosić ad extra. Dlatego też druga część referatu poświęcona jest ewangelizacji.

\section{WARTOŚĆ SŁOWA W KSZTAŁTOWANIU KULTURY}

W przemówieniu w Kolegium Bernardynów papież ukazuje bezpośredni związek chrześcijaństwa w Europie z początkami cywilizacji europejskiej, której scalanie, ujednolicanie dokonywało się wobec zagrożenia rozbiciem w czasie tzw. wędrówki ludów. Benedykt XVI odwołuje się do tego procesu wędrówki ludów kluczowego dla kształtowania nowych fundamentów Europy, która pozbawiona została dotychczasowego spoiwa, jakim była idea cesarstwa rzymskiego. Wobec upadku dawnego paradygmatu kulturowego ludy kształtujące swoją tożsamość potrzebują nowego czynnika jednoczącego i tym czynnikiem staje się chrześcijaństwo. Christianitas - chrześcijański fundament wartości staje się podłożem tworzącym nową kulturę. Życie monastyczne przybrało w tym czasie formę swoistego pomostu pomiędzy kulturą antyczną, w kształtującą się dopiero nową kulturą europejskich ludów.

Benedykt XVI zaznacza, że pierwotnym celem mnichów nie było kształtowanie nowej kultury, lecz quaerere Deum - poszukiwanie Boga. Ich poszukiwania były ukierunkowane eschatologicznie, skupiały się na tym, co ostateczne. Poszukiwanie to papież określa mianem drogi, wskazując na jego dynamiczny charakter, a jednocześnie podkreślając pewną systematyczność, podejście o charakterze programowym. Motyw drogi wskazuje na dynamizm, proces, który wymaga czasu, drogę wyznacza Słowo.

Droga ta stała się dla nich zrozumiała dzięki odkryciu Tego, które sam siebie określił mianem Drogi, Prawdy i Życia (por. J 14,6), Boga, który 
dał się rozpoznać w swoim Słowie. To odkrycie motywowało mnichów do podjęcia poszukiwania na poziomie gramatyki, prowadzącej do poznania i umiłowania słowa, którym Bóg się posłużył, aby człowiek mógł poznać i umiłować Słowo Wcielone, Jezusa Chrystusa, w którym objawia się pełnia Bożej Mądrości i Miłości. Taka metodologia poszukiwań, jaką zastosowali mnich ukazuje drogę zstępującą w poznawaniu rzeczy ostatecznych. „W słowie biblijnym Bóg idzie do nas, a my do Niego, i dlatego mnisi musieli uczyć się zgłębiać tajniki języka, rozumieć jego strukturę i zastosowania" słowa, która przyjmuje rolę służebną wobec umiłowania Prawdy ${ }^{8}$. Dlatego też Benedykt XVI wskazuje na dwa zasadnicze miejsca, które w strukturze klasztoru służyły spotkaniu ze Słowem: „szkoła i biblioteka zapewniały wykształcenie umysłu i eruditio, a na jego podstawie człowiek uczy się pośród wielu słów dostrzegać jedyne Słowo" ${ }^{\prime}$. Metodologia Benedykta pozwala przejść od eschatologii do gramatyki, od odwiecznego Słowa Boskiego Logosu do słowa, które jest nośnikiem treści Mądrości - Logosu. Dlatego uprawnionym jest przejście droga Logos - Słowo, słowo - kultura języka, literatura - biblioteka, szkoła.

O ile Słowo Boże kształtuje każdego indywidualnie, buduje indywidualną relację z Bogiem, co wymaga osobistego zaangażowania, o tyle to samo Słowo kreuje także wrażliwość na drugiego człowieka i otwiera na wspólnotę. Daje się to zauważyć w stylu życia mnichów, którzy nie zatrzymują się na mistyce indywidualnej, ale troszczą się o czytanie Słowa we wspólnocie, aby to Słowo mogło służyć wszystkim, „którzy pielgrzymują w wierze"10.

Podobną drogę - od indywidualnego spotkania ze Słowem do Słowa rozważanego we wspólnocie - Benedykt XVI ukazuje, analizując odpowiedź człowieka na Słowo. Bóg zaprasza nas do dialogu, a więc słuchania i odpowiedzi. Słowo motywuje, wzywa i uzdalnia do odpowiedzi, jaką jest modlitwa, która również nie zatrzymuje się na indywidualnej reakcji, ale wyrażone jest w symfonii odpowiedzi, jakie płyną ze wspólno-

7 Benedykt XVI, Fundamentem prawdziwej kultury jest poszukiwanie Boga, „L'Osservatore Romano”, edycja polska, 2008 (10-11), s. 13.

${ }^{8}$ Por. E. Guerreiro, Świadek prawdy, Kraków 2018, s. 469.

9 Benedykt XVI, Fundamentem prawdziwej kultury, s. 13.

10 Tamże. 
ty. Analogią, do jakiej sięga Benedykt XVI, jest śpiew i muzyka, nadająca ludzkim słowom szczególną wymowę. Dla św. Benedykta śpiew mnichów miał swoje źródło i pierwowzór w anielskim uwielbieniu Boga. Śpiew, który ma być naśladowaniem i odzwierciedleniem boskiej liturgii wyznacza także zadanie dla kultury - nie jest ona jedynie autonomicznym wytworem ludzkiej działalności, ma być odzwierciedleniem Mądrości Stwórcy. Słowo ludzkie ma być odbiciem Słowa - Logosu. Dzieło człowieka ma być odbiciem dzieła Boga. To podobieństwo pociągało za sobą daleko idące wnioski przekładające się na życie całej wspólnoty. Wspólnota mnichów miała być regio similitudinis, miała odzwierciedlać niebieski dwór, królestwo niebieskie. Takie też było zadanie kultury, jaka kształtowała się na bazie umiłowania słowa, wyrażonego w trosce o kulturę słowa, literaturę, modlitwę i śpiew. Kultura, oderwana od tego niebiańskiego pierwowzoru, nieoddająca swoim kształtem swego boskiego źródła i przeznaczenia, staje się drogą do „regio dissimilitudinis, krainy, gdzie wszystko jest na opak”11.

Daje się już zauważyć podkreślana przez Benedykta XVI, w odniesieniu do różnych aspektów życia wspólnoty mnichów, konieczna zależność między indywidualnym a wspólnotowym udziałem człowieka w tworzeniu kultury. Pierwszorzędną analogią jest Słowo Boże zapisane na kartach Pisma Świętego. Podobnie, jak Pismo Święte kształtowało się we wspólnocie, która żyła Słowem Bożym, tak również ma być interpretowane i przekazywane. Stanowi to wysiłek, którego nie jest w stanie wyczerpać ani jednostka, ani nawet jedno pokolenie. Pismo Święte stanowi wyzwanie interpretacyjne dla wszystkich pokoleń ${ }^{12}$. Wspólnotowość w podejściu do Słowa Bożego strzeże chrześcijanina przed fundamentalizmem, subiektywizmem, pozwala uczynić właściwy użytek z wolności. Podsumowaniem tych rozważań niech będą słowa Benedykta XVI, w których przestrzega przed fałszywym zastosowaniem wolności w kształtowaniu kultury: „Gdyby dzisiejsza kultura europejska traktowała wolność jako totalny brak więzi, byłoby to rzeczą zgubną i prowadziłoby nieuchronnie do fanatyzmu i arbitralności. Brak więzi i arbitralność nie są wolnością, ale jej destrukcją"13.

\footnotetext{
11 Tamże, s. 14.

12 Por. E. Guerreiro, dz. cyt., s. 469.

13 Benedykt XVI, Fundamentem prawdziwej, s. 15.
} 


\section{WARTOŚĆ LUDZKIEJ PRACY}

Benedykt XVI wskazuje na różnicę, jaka zachodzi w rozumieniu pracy pomiędzy światopoglądem antycznym, a modelem wypracowanym na gruncie kultury biblijnej. Dla monastycyzmu, który kształtował kulturę średniowiecznej Europy, praca stanowiła element konstytutywny. Praca miała odzwierciedlać stwórcze działanie samego Boga, które nie zamyka się jedynie w akcie powołania świata do istnienia, ale odnosi się zarówno do creatio continua, jak również do wewnętrznego życia Trójcy Świętej, które jest fundamentem ekonomii zbawczej. Wobec tego praca nie jest już realizacją niewolniczego posłuszeństwa, lecz podejmowanym w sposób wolny naśladowaniem Stwórcy. Benedykt XVI powołuje się na judaistyczną tradycję, w której mędrzec i nauczyciel oddawał się również pracy rzemieślniczej (np. św. Paweł). Praca rozumiana była jako wejście w sferę działania Boga - Stwórcy, który działa w dziejach człowieka, a sam Jezus Chrystus ma swój udział w tym tworzeniu historii poprzez akt Wcielenia. Swoistym novum, o jakim mówi Benedykt XVI jest miejsce człowieka w tym kształtowaniu świata przez pracę:

Oryginalność tego etosu powinna jednak uświadamiać, że praca wraz z kształtowaniem historii przez człowieka są współdziałaniem ze Stwórcą, których On jest miarą. Tam, gdzie brak tej miary, i tam, gdzie człowiek wynosi samego siebie do rangi ubóstwionego stwórcy, przekształcenie świata może $\mathrm{z}$ łatwością doprowadzić do destrukcji ${ }^{14}$.

To jedno z bardziej stanowczych zdań, jakie padły w czasie papieskiego przemówienia. Papież przestrzega przed absolutyzacją ludzkich dążeń $\mathrm{w}$ podejściu do pracy i w konsekwencji w kształtowaniu kultury. To stanowcze ostrzeżenie przed ubóstwianiem ludzkich zdolności stwórczych jest jednocześnie wezwaniem do odbudowywania wciąż na nowo właściwej hierarchii wartości. Prymat Boga w podejmowanych przez człowieka twórczych zamierzeniach jest jedynym fundamentem i gwarantem harmonijnego rozwoju ludzkiej kultury i jednocześnie ukierunkowuje na cel, jakim powinno być prawdziwe dobro. W tym jednym zdaniu papież zawarł niejako syntezę swojego nawoływania do nowego humanizmu

14 Tamże. 
mającego swój początek i cel w Bogu, Stwórcy i Odkupicielu człowieka. Tylko taka historiozbawcza perspektywa ludzkiej pracy i ludzkiej kultury daje nadzieję na to, że człowiek swoją wielkość będzie budował nie na samookreśleniu siebie i przekonaniu o zdolności do samozbawienia, lecz będzie kształtował siebie w duchu zachwytu wyrażonego słowami psalmisty: „Sławię Cię, żeś mnie tak cudownie stworzył, godne podziwu są Twoje dzieła" (Ps 139,14) oraz Czymże jest człowiek, że o nim pamiętasz, i czym syn człowieczy, że się nim zajmujesz?” (Ps 8,5).

Dla Benedykta XVI praca ma zatem swoje źródło zarówno w trynitarnej naturze Boga (Bóg, który swym życiem ubogaca świat), jak i w tajemnicy Wcielenia (Bóg, który wkracza w doczesną sytuację człowieka). Człowiek w swoich twórczym nastawieniu powinien dążyć do naśladowania Boga, poprzedzonego poszukiwaniem Boga i pełnym zachwytu wsłuchiwaniem się w Słowo. Praca ludzka jest więc kolejną sferą ludzkiej działalności, która odsłania wpisane w ludzką naturę quaerere Deum.

\section{POTRZEBA NIEUSTANNEJ EWANGELIZACJI}

W pierwszej, zasadniczej części swego przemówienia, Benedykt XVI zwraca uwagę na konieczność poszukiwania Boga, który w swoim Słowie pozostawia nam drogę, która jako jedyna prowadzi do budowania kultury kształtującej pełny obraz Boga w człowieku. Druga, nie mniej doniosła w swej treści dotyczy znaczenia i potrzeby ewangelizacji.

Poszukiwanie Boga było tym impulsem, który wyznaczał rytm i sposób życia wspólnoty mnichów. W swoim rozważaniu Benedykt XVI zwraca uwagę na ten wewnętrzny impuls, który jest wezwaniem do podjęcia drogi poszukiwania, impuls, który zapoczątkowuje w człowieku pragnienie szukania. Kolejnym krokiem jest odkrycie w Słowie Bożym wiarygodnej drogi, która pozwoli zrealizować to pragnienie. Aby człowiek był w stanie odnaleźć w sobie pragnienie Boga i doświadczyć spotkania ze Słowem, które wzywa do poszukiwania konieczna jest ewangelizacja, a więc głoszenie Słowa. Fundamentalnym dla Benedykta XVI wezwaniem do głoszenia są słowa z Pierwszego Listu św. Piotra: „bądźcie zawsze gotowi do obrony wobec każdego, kto domaga się od was uzasadnienia tej nadziei, która w was jest” (1 P 3,15). Papież wyjaśnia dalej, że ko- 
nieczność ewangelizacji nie jest wyznaczona jedynie przez potrzeby samej wspólnoty. Ewangelizacja nie jest motywowana jedynie socjologicznym podejściem nakazującym pozyskiwanie nowych członków zapewniających trwałość i ciągłość istnienia wspólnoty. W dzieło ewangelizacji wpisana jest wewnętrzna potrzeba dzielenia się Słowem, które daje życie. Wyrazić to można słowami, jakimi apostołowie Piotr i Jan odpowiadają na zakaz głoszenia prawdy o Jezusie Chrystusie, nałożony na nich przez Sanhedryn: „my nie możemy nie mówić tego, cośmy widzieli i słyszeli” (Dz 4,20). Owo non possumus wynika $\mathrm{z}$ tego samego wewnętrznego nakazu, jaki zawiera się w Chrystusowym trzeba (gr. dei) - „Syn Człowieczy musi wiele wycierpieć” (Łk 9,22), które wyraża nie tyle przymus wyznaczony przez jakąś wyższą instancję, ile posłuszeństwo woli Ojca, ale i wewnętrzny impuls mówiący, że tylko taka droga prowadzi do najwyższego dobra. W ten sposób wspólnota głosząca Słowo staje się niejako matką, która rodzi nowego człowieka i karmi go najwspanialszym pokarmem, jaki dane jej było odkryć.

W misji ewangelizacyjnej daje się również rozpoznać powszechność ludzkiego rozumu, który jest otwarty na działanie Boga, który również daje się rozpoznać każdemu, bez względu na różnice kulturowe, ponieważ w ewangelizację wpisana jest także troska o poszukiwanie prawdy. Papież daje temu wyraz w czasie konferencji prasowej na pokładzie samolotu podczas podróży do Francji. Podkreśla, jak ważne jest docenienie wolności i piękna, jakie niesie z sobą wiara. Źródłem tego piękna jest możliwość poznania Boga o ludzkim obliczu Jezusa Chrystusa ${ }^{15}$.

W przemówieniu w Kolegium Bernardynów, w odniesieniu do sposobu ewangelizacji, Benedykt XVI odwołuje się do mowy św. Pawła na Areopagu. Porównując ówczesną sytuację do kultury XXI wieku, papież wskazał na liczne podobieństwa. Dzisiejszy świat staje się często przestrzenią, w której Bóg pozostaje wielkim Nieznanym, jednak ciągle obecna jest tęsknota i pełne niepokoju pytanie o Niego. Fakt Wcielenia odsłania przed nami zupełnie nowe możliwości poznania Boga:

${ }_{15}$ Por. Benedykt XVI, Konferencja prasowa w samolocie, „L'Osservatore Romano”, edycja polska, 2008 (10-11), s. 8. 
Nowość chrześcijańskiego orędzia nie zawiera się w myśli, lecz w fakcie: Bóg się nam objawił. I nie jest to jedynie sam akt objawienia, ale prawda, że On sam to Logos - obecność wiecznego Rozumu w naszym ciele. Verbum caro factum est (J 1, 14): tak jest naprawdę w rzeczywistości, teraz, Logos jest tu, Logos jest obecny pośród nas. To fakt racjonalny ${ }^{16}$.

Bóg, który daj nam się poznać, wzywa nas do działania. Słowo domaga się głoszenia, niczym ziarno, które domaga się, aby zostało wrzucone w ziemię. Podczas nieszporów w katedrze Notre Dame papież podkreślił, że właśnie ze względu na fakt Wcielenia Słowo Boże stało się duszą apostolatu ${ }^{17}$.

Po raz kolejny Benedykt XVI odwołuje się także do rozumnej natury człowieka, podkreślając, że racjonalność jest równouprawnioną płaszczyzną poszukiwania Boga oraz głoszenia Jego Słowa we współczesnym świecie. Papież występuje przeciwko roszczeniom pozytywistycznej kultury, która wiarę i teologię w jej pytaniem o Boga degraduje do roli subiektywistycznej i nienaukowej dziedziny. Zdaniem Benedykta XVI takie pozbawienie człowieka racjonalnej, naukowej refleksji nad Słowem Bożym prowadzi do zubożenia ludzkich możliwości poznawczych. Papież nazywa takie podejście kapitulacja rozumu i porażką humanizmu ${ }^{18}$. Słowa te zostały wypowiedziane w miejscu, które ze względu na swoją historię i jednocześnie przewidziany cel nosi w sobie aspiracje do bycia współczesnym Areopagiem dla budowania pomostu między wiarą i rozumem na gruncie europejskiej kultury.

Przekonanie o tym, że tylko rozum pojednany z wiarą, by wspólnie podążać drogą poszukiwania prawdy wypływa także z treści homilii wygłoszonej podczas Mszy św. na Placu Inwalidów. Papież mówił wtedy o więzi, jaka łączy rozum i wiarę, które ze swej natury nie pozostają ze sobą w konflikcie:

Bóg nigdy nie domaga się od człowieka ofiary ze swojego rozumu! Rozum nigdy nie wchodzi w rzeczywisty konflikt $\mathrm{z}$ wiarą! Jedyny Bóg, Ojciec,

16 Tenże, Fundamentem prawdziwej kultury, s. 16.

17 Por. tenże, Słowo Boże jest dusza apostolatu i życia kapłańskiego, „L’Osservatore Romano", edycja polska, 2008 (10-11), s. 19.

18 Tenże, Fundamentem prawdziwej kultury, s. 16. 
Syn i Duch Święty, stworzył nasz rozum i daje nam wiarę, proponując, byśmy w wolności przyjęli ją jako cenny dar ${ }^{19}$.

Dlatego też zarówno rozum, jak i wiara są płaszczyzną, na której każdy człowiek doświadcza pragnienia poszukiwania Boga.

\section{NADZIEJA DLA WSPÓłCZESNEJ KULTURY}

Papieskie przesłanie wygłoszone w Kolegium Bernardynów wydaje się odsłaniać całość orędzia skierowanego zarówno do Francuzów, jak i do całej zachodniej Europy w czasie pielgrzymki do Francji w dniach 12-15 września 2008 roku. Z przemówień wygłoszonych w czasie apostolskiej podróży płynie pełne nadziei przekonanie, że dzisiejsze czasy, mimo iż noszą na sobie znamiona kryzysu wiary, sprzyjają powrotowi do Boga. Poczucie zagubienia, jakie daje się zauważyć na płaszczyźnie kulturowej, każe na nowo podjąć wysiłek poszukiwania nowych trwalszych wartości, co otwiera przestrzeń o charakterze eschatologicznym, ponieważ każe skupić się również na poszukiwaniu odpowiedzi na pytania o rzeczy ostateczne.

Refleksja nad korzeniami europejskiej kultury Zachodu pokazuje zatem, że ma ono swój początek w nastawieniu wiary. Wtórne wobec kształtowania kultury jest poszukiwanie Boga. Metodologia poszukiwania źródeł kultury prowadzi do zbudowania hierarchii źródeł. U szczytu tej hierarchii jest pragnienie Boga. Człowiek jest najpierw capax Dei, a później twórcą. Poszukiwaniu Boga towarzyszy refleksja racjonalna oparta także na pewnym schemacie aksjologicznym, szacowaniu wartości dóbr. Dobra przemijające ustępują miejsca dobrom nieprzemijającym w sytuacji kryzysowej.

Sytuacja kryzysowa nie tylko pomaga, co wręcz wymusza rewolucję aksjologiczną, która w konsekwencji prowadzi do ukształtowania się hierarchii wartości, w której Bóg znajduje się na pierwszym miejscu. W przemówieniu wygłoszonym w auli Pawła VI po zakończeniu pielgrzymki do Francji Benedykt XVI zauważył, że poszukiwanie Boga wyznaczało drogę Europie, która przeżywała kryzys już u początku kształtowania się

${ }_{19}$ Tenże, Rozum nigdy nie jest $w$ sprzeczności $z$ wiara, „L'Osservatore Romano”, edycja polska, 2008 (10-11), s. 23. 
jej chrześcijańskich korzeni: „W epoce głębokiego kryzysu starożytnej cywilizacji mnisi, kierując się światłem wiary, wybrali najdoskonalszą drogę - drogę słuchania Słowa Bożego"20. W ten sposób orędzie papieża staje się również wezwaniem, by obecny kryzys, który dotyka współczesną Europę, wyzwolił również analogiczną odpowiedź na potrzebę odnowy życia. Także dziś potrzeba zgody na to, by Bóg światłem wiary wskazał nam na nowo drogę słucha Słowa, które przyjęte i poznane da podwaliny pod budowę kolejnych wspólnot gotowych do podejmowania ewangelizacyjnej misji zasiewania tego Słowo i dawania nowego impulsu pragnieniu poszukiwania Boga w tych, którzy to pragnienie w sobie zgasili.

Ta myśl towarzyszyła papieżowi Benedyktowi XVI aż do końca pontyfikatu. Jednym w głównych powodów ogłoszenia Roku Wiary była konieczność odnowienia potrzeby wiary w tych, którzy swoje życie kształtują w oparciu o wartości, które nie wypływają z wiary. W Liście Porta Fidei papież wskazał na potrzebę odnowienia pragnienia podążania za Słowem Bożym:

Współczesny świat potrzebuje dziś szczególnie wiarygodnego świadectwa tych, których umysły i serca oświecone są Słowem Bożym i zdolni są otworzyć serca i umysły tak wielu ludzi na pragnienie Boga i prawdziwego życia, które nie ma końca (Porta Fidei 15) ${ }^{21}$.

Temat podjęty w czasie wizyty we Francji był wielokrotnie rozwijany przez papieża przy okazji rozmaitych spotkań tak z przedstawicielami świata kultury jak i w czasie spotkań z biskupami i pracownikami Kurii Rzymskiej. Wystarczy choćby wspomnieć o swego rodzaju programowym określeniu dziedziniec pogan, który stał się podwaliną pod szereg inicjatyw podejmowanych $\mathrm{w}$ ramach nowej ewangelizacji. W przemówieniu do Kurii Rzymskiej wygłoszonym 21 grudnia 2009 r. papież zwrócił uwagę na konieczność otworzenia w Kościele przestrzeni dla dialogu z niewierzącymi, którzy noszą w sobie pragnienie poszukiwania:

${ }^{20}$ Tenże, Dziękuje goraco Bogu za podróż do Francji, „L’Osservatore Romano”, edycja polska, 2008(10-11), s. 42.

${ }^{21}$ Tenże, List apostolski «motu proprio» Porta Fidei, „L'Osservatore Romano”, edycja polska, 2011(12), s. 9. 
Uważam, że Kościół powinien również dzisiaj otworzyć swego rodzaju dziedziniec pogan, gdzie będą mogli w jakiś sposób zbliżyć się do Boga ludzie, którzy Go nie znają, zanim znajdą drogę do Jego tajemnicy, której służy życie wewnętrzne Kościoła. Do dialogu z religiami powinien dzisiaj dołączyć się przede wszystkim dialog z tymi, którym religia jest obca, którzy nie znają Boga, a jednak nie chcą pozostać po prostu bez Boga, lecz pragną przynajmniej zbliżyć się do Niego jako do Nieznanego ${ }^{22}$.

Słowa papieża były wezwaniem do tego właśnie impulsu, o którym mówił w Kolegium Bernardynów Paryżu. Nie chodzi jedynie o samą proklamację Słowa, ale o stworzenie przestrzeni spotkania dla tych, którzy pociągnięci Słowem chcą na stałe przylgnąć do Boga, który przestał być Nieznanym, a którego poznawszy chcą pokochać i według Jego Słowa żyć. Wezwanie to znalazło swoje odzwierciedlenie w fundacji o nazwie Dziedziniec pogan, powołanej przez Papieską Radę ds. Kultury, która zrealizowała szereg spotkań służących dialogowi z poszukującymi. O tej potrzebie i o otwartości, jaka cechuje niewierzących, Benedykt XVI napisał również, już jako emeryt, w przesłaniu do uczestników debaty Dziedziniec pogan zorganizowanej w Warszawie w 2017 roku. Zwrócił wtedy uwagę na niemilknące pytania o pochodzenie i cel człowieka. Te pytania są wspólne zarówno wierzącym, jak i ateistom, dlatego także kwestii istnienia Boga nie da się przemilczeć. Wobec tych fundamentalnych pytań Benedykt XVI zwraca uwagę na obecną nawet $\mathrm{w}$ niewierzących nadzieję, która jest miejsce obecności Boga i dlatego tak bardzo konieczny jest wysiłek odkrywania i rozświetlania tej nadziei i wraz z nią - obecności Boga w człowieku ${ }^{23}$.

Konieczność ewangelizacji ma zatem swoje źródło w eschatologicznym ukierunkowaniu życia tak indywidualnego, jak i wspólnotowego. Myślenie eschatologiczne wskazuje na celowość działań. Poszukiwanie rzeczy ostatecznych stanowi o otwarciu na Boga, nawet jeżeli pozostaje On jeszcze Nieznanym Bogiem.

${ }^{22}$ Tenże, Jesteśmy przyjaciólmi tych, którzy znaja Boga, i tych, którzy Go jeszcze nie znają, 21 XII 2009 - Przemówienie do Kurii Rzymskiej, „L'Osservatore Romano”, edycja polska, 2010 (2), s. 41.

${ }^{23}$ Por. Benedykt XVI napisał słowo powitalne do uczestników „Dziedzińca Dialogu”, http://wiez.com.pl/2017/10/16/benedykt-xvi-napisal-slowo-powitalne-do-uczestnikowdziedzinca-dialogu, (dostęp: 12.11.2019). 


\section{ZAKOŃCZENIE}

Benedykt XVI, poszukując źródeł kultury europejskiej, wskazuje na życie monastyczne, zbudowane na zachwycie nad Słowem. U podstaw tego zachwytu leży pragnienie poszukiwania Boga. Każdy intelektualny wysiłek miał pomagać w otwarciu się na Prawdę objawioną w Bożym Słowie. Słowo kształtowało indywidualną relację z Bogiem, zapraszało do dialogu i budowało w ten sposób potrzebę życia we wspólnocie. Z troski o Słowo Boże zrodziła się troska o słowo ludzkie, stąd systematyczna refleksja, jaka dokonywała się w klasztornych szkołach, bibliotekach, a następnie przeradzała się w modlitewny dialog ze Stwórcą wyrażony w modlitwie i śpiewie. Efektem owego poszukiwania Boga jest całokształt wytworów działania ludzkiego intelektu, a więc szeroko pojęta kultura, która od samego początku czerpie z chrześcijańskich wzorców. Benedykt XVI wskazuje na potrzebę ewangelizacji, mającej budzić na nowo pragnienia poszukiwania Boga poprzez kulturę, która we współczesnym świecie przeżywa kryzys oderwania od wartości religijnych. Przemówienie Benedykta wygłoszone w Kolegium Bernardynów jest więc pełnym nadziei wołanie o powrót do źródła, jakim jest Słowo, kształtujące ludzki intelekt na obraz i podobieństwo Stwórcy.

\section{BIBLIOGRAFIA}

Benedykt XVI, Dziękuje gorąco Bogu za podróż do Francji, „L'Osservatore Romano”, edycja polska, 2008 (10-11), s. 42-43.

Benedykt XVI, Fundamentem prawdziwej kultury jest poszukiwanie Boga, „L'Osservatore Romano", edycja polska, 2008 (10-11), s. 12-16.

Benedykt XVI, Jesteśmy przyjaciólmi tych, którzy znaja Boga, i tych, którzy Go jeszcze nie znaja, 21 XII 2009 - Przemówienie do Kurii Rzymskiej, „L'Osservatore Romano”, edycja polska, 2010 (2), s. 37-41.

Benedykt XVI, Konferencja prasowa w samolocie (12.03.2008), „L'Osservatore Romano”, edycja polska, 2008 (10-11), s. 8.

Benedykt XVI, List apostolski «motu proprio» Porta Fidei, „L'Osservatore Romano”, edycja polska, 2011 (12), s. 4-10.

Benedykt XVI, Rozum nigdy nie jest w sprzeczności z wiarą, „L'Osservatore Romano”, edycja polska, 2008 (10-11), s. 23-25.

Benedykt XVI, Słowo Boże jest dusza apostolatu i życia kapłańskiego, „L'Osservatore Romano", edycja polska, 2008 (10-11), s. 17-19. 
Guerreiro Elio, Świadek prawdy, Kraków 2018.

Kindziuk Milena, Benedykt XVI o kulturze, http://e-civitas.pl/benedykt-xvi-o-kulturze (dostęp: 12.11.2019).

Ratzinger Joseph, Europa Benedykta w kryzysie kultur, Częstochowa 2005.

Ratzinger Joseph, Ku dojrzałości wiary w Chrystusa. Homilia w czasie Mszy „pro eligendo pontifice”, „L'Osservatore Romano”, edycja polska, 2005 (6), s. 29-31.

Ratzinger Joseph, W rozmowie z czasem, Opera omnia t. XIII/3, Lublin 2018.

Regoli Roberto, Benedykt XVI. Wielki papież czasu kryzysu, Kraków, 2017. 